\title{
A Framework for Assessing Spatial Distribution of Soil Properties in Levee Systems Based on Underlying Geology and River Morphology
}

\author{
Mustafa Saadi ${ }^{1} \&$ Adda Athanasopoulos-Zekkos ${ }^{1}$ \\ ${ }^{1}$ Civil and Environmental Engineering, University of Michigan, Ann Arbor MI, USA \\ Correspondence: Adda Athanasopoulos-Zekkos, Civil and Environmental Engineering, University of Michigan, \\ Ann Arbor MI, 48109 USA. Tel: 1-734-764-0057. E-mail: addazekk@umich.edu
}

Received: April 30, 2013 Accepted: June 14, 2013 Online Published: June 19, 2013

doi:10.5539/jgg.v5n3p22 URL: http://dx.doi.org/10.5539/jgg.v5n3p22

\begin{abstract}
Flood protection systems are complex, interconnected engineered systems, where failure at one location means the failure of the entire system. Earthen levees, the systems' major component, are at risk from many causes of failure including seepage, overtopping, erosion and instability due to seismic loading. Levees stretch for long distances and are formed through various geologic processes and human activities over time, however information regarding soil properties is collected only at limited point locations and varies significantly both laterally and with depth. Prediction of levee performance in locations where no soil data is available becomes a limitation for system risk assessment studies.

This study attempts to test the hypotheses that spatial variability of soil properties is correlated to regional variables such as distance from nearest river segment, river meandering sinuosity index and surface geology. A geostatistical ordinary kriging approach was used for developing these correlations. The specific areas used for data collection and analysis and model development in this study were sub-sections of the larger Sacramento River Flood Control Project (SRFCP) in northern California. Soil strength parameters of identified levee stratigraphy layers were statistically analyzed using a geostatistical ordinary kriging approach and correlated to preselected regional variables. Global observations that applied across the study area included the increasing trend of undrained shear strength for cohesive soils, Su, with increasing distance from the river, and decreasing trend of Su with increasing river Sinuosity Index levels. Only local trends were observed in the relation of friction angle of cohesionless soils, $\phi$, with Sinuosity Index, as well as in the relation of $\mathrm{Su}$ and $\phi$ with geological formations.
\end{abstract}

Keywords: earthen levees, engineered systems, flood protection, GIS, spatial variability, geostatistics

\section{Introduction}

Flood protection systems are important parts of the civil infrastructure of the United States. Recent natural disasters like Hurricane Katrina have provided warnings with regards to the need to maintain and upgrade the aging and deteriorating flood protection systems. Furthermore, the American Society of Civil Engineers (ASCE), in its most recently released Infrastructure Report Card (ASCE, 2009), gave the country's infrastructure an overall average performance grade of D. The newest infrastructure category, levees, received a D-. The Department of Water Resources (DWR) in California is currently helping lead the efforts for improving the nation's flood protection infrastructure by re-evaluating the vulnerability of the flood protection systems in the San Joaquin and Sacramento River Valleys and in the Sacramento Delta region (DWR, 2011; URS, 2008).

The vast majority of U.S. river cities, now growing at increasing rates, are protected from flooding by earthen levees. Present day earthen levees are at risk from many causes of failure (Figure 1) including seepage (both under-seepage and through-seepage), erosion and instability due to seismic loading. Seismic loading is a potentially grave hazard in many areas of the nation. Guidelines for a seismic element of levee design have never been implemented as a national standard practice, so there are many thousands of miles of seismically vulnerable levees throughout the nation (Figure 2).

Levee response and performance is dependent on the loading condition, as well as the levee geometry and the properties of the levee materials and the foundation soils. Due to the large physical extent of such systems along rivers and canals, and in the absence of as-built documentation, soil investigation data is at best available at 
scattered intervals along the levee length, carries a high level of uncertainty, and can be inconsistent, unreliable or incomplete depending on when and by whom the investigation was carried out.

Earthen flood protection systems are complex, interconnected, adaptive engineered systems where failure at one location means failure of the system, and failure at different locations may result in flooding of different areas. The general risk assessment aspect of such engineered systems has recently become the topic of research efforts such as the Resilient and Sustainable Infrastructure Networks project (RESIN, 2011). However, even though levees stretch for long distances and are in part formed through various geologic processes and human activities over time, information regarding soil properties is collected only at a limited number of point locations and can vary significantly both laterally and with depth. Hence, this becomes a limitation in prediction of the performance of levees in locations where no soil data is available. Analyses with regard to levee vulnerability were performed to date only at locations with known soil properties (DRMS, 2006a, 2006b; URS, 2008). A simplified procedure for the assessment of seismic vulnerability at a particular levee location with known soil properties has been proposed (Athanasopoulos-Zekkos, 2008; Athanasopoulos-Zekkos \& Seed, 2013) and is currently being adopted within the Urban Levee Project led by URS Corp. for the Department of Water Resources in California and the under development USACE Guidelines for Seismic Evaluation of Levees, (USACE, 2013). The spatial continuity of the results however, is particularly critical in levee systems since failure of a levee at any location could result in the failure of the function of the overall flood protection system. The estimate of the earthen levee response in locations with no available soil data therefore becomes an issue of major concern. As such, it is critically important to develop an approach for assessing the risk of failure continuously along the length of levees.

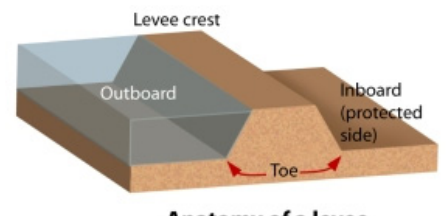

Anatomy of a levee
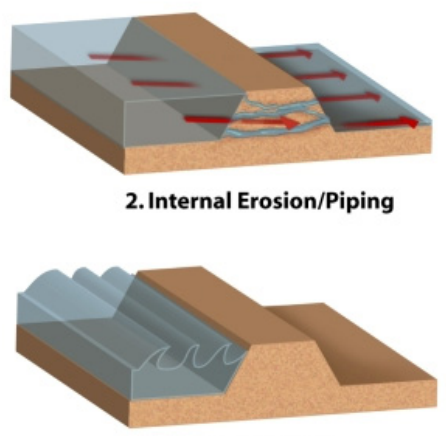

5. Wave Impacts

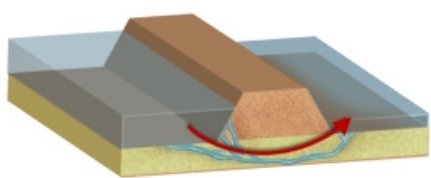

8. Piping of substratum

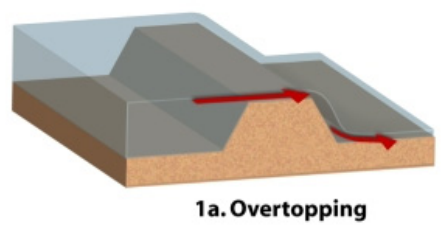

1a. Overtopping
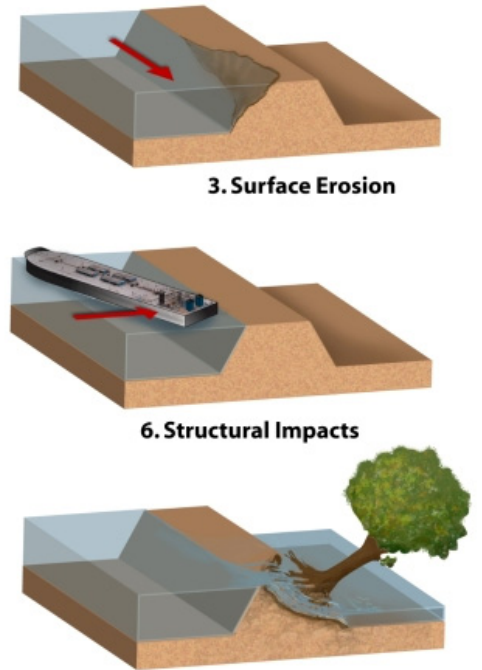

9. Tree damage
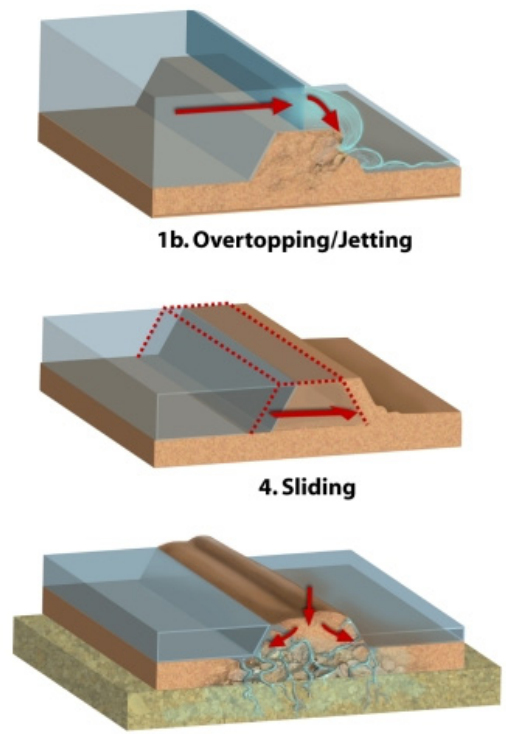

7. Liquefaction

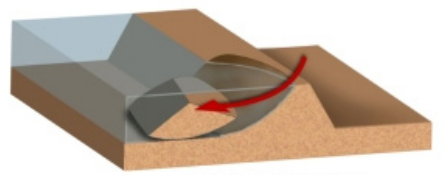

10. Slope failure

Figure 1. Basic levee failure mechanisms (Deretsky, 2010) 

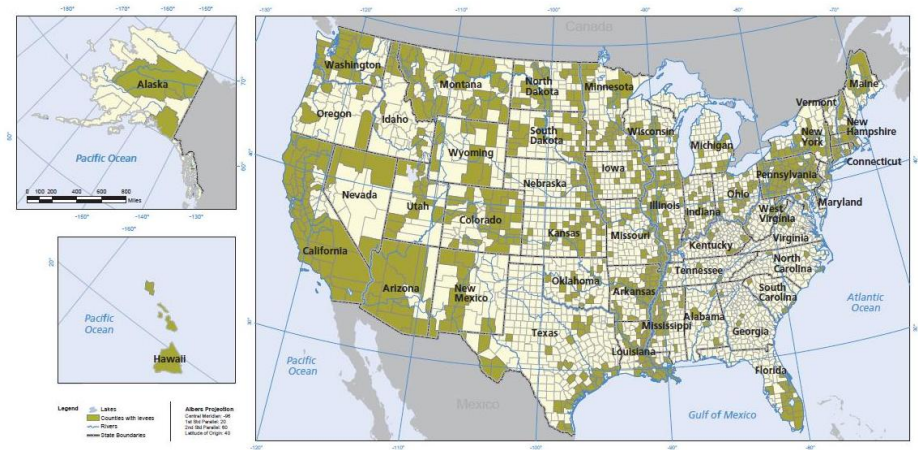

(A)

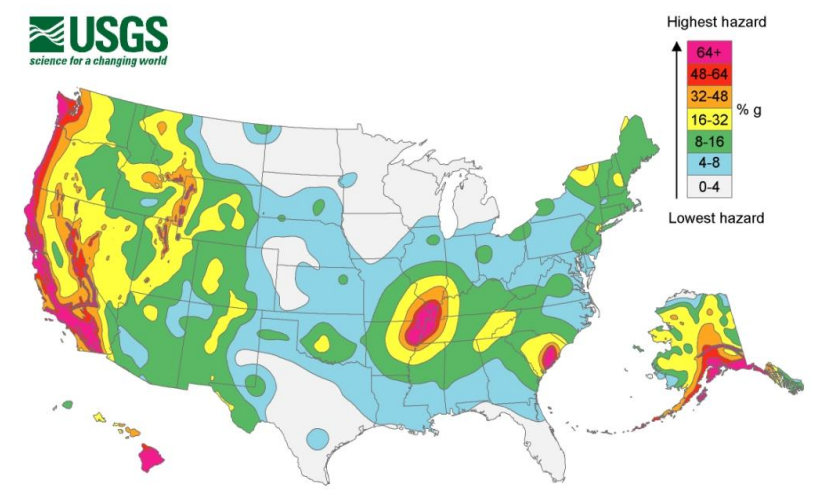

(B)

Figure 2. (A) Map of United States counties that contain levees (ASCE, 2010) and (B) National Seismic Hazard

Map across the United States showing the levels of horizontal shaking that have a 2-in-100 chance of being exceeded in a 50-year period. Shaking is expressed as a percentage of $\mathrm{g}$, the acceleration of a falling object due to gravity (USGS, 2008)

\section{Previous Work on Spatially Distributed Soil Properties}

Soils and rocks in their natural state are among the most variable of all engineering materials. Quantitative measurements of soil properties in the early 1900's differentiated the new discipline of soil mechanics from the engineering of earth works in the previous periods. However, these measurements revealed a great amount of variability in properties, not only from site to site and layer to layer, but even within what seemed to be a homogenous material (Baecher \& Christian, 2008). The variation in these parameters, due to inherent variations in composition and consistency during formation, is thus a three dimensional problem that involves the vertical stratification at any given point, as well as the planar deviations within a specific layer.

Ranges of data variation for soil property parameters have been reported by many researchers, especially starting in the 1960's (Lacasse \& Nadim, 1996; Lee et al., 1983; Lumb, 1966, 1974). Despite the work that has been done on this issue, it is not a closed matter, and more needs to be done, particularly on quantifying the level of additional effort required to improve existing characterization of a particular site (Christian \& Baecher, 2011).

One way to measure the variability of soil properties is similar to the work by Phoon and Kulhawy (1996). The extent, to which soil data might vary, is measured by the coefficients of variation (COV) for a variety of soil properties (Table 1). The COV is defined as the standard deviation divided by the mean. The range of values of the COV is large and is only reflective of conditions at a particular site. As such, there is a need for extending such measures of variability beyond site specific conditions, and applying them to more general conditions of geological or geographical environments such as riverine or deltaic regions, as is the case in this study. Furthermore, although some of the general trends of variability in soil and rock can be anticipated, the uncertainty in practice can be larger than expected, with significant implications to geotechnical design and analysis (Christian \& Baecher, 2011). 
Table 1. Coefficient of variation for common field measurements (Phoon \& Kulhawy, 1996)

\begin{tabular}{|c|c|c|c|c|c|}
\hline Test type & Property & Soil type & Mean & Units & $\operatorname{COV}(\%)$ \\
\hline \multirow{3}{*}{$\mathrm{CPT}$} & $\mathrm{q}_{\mathrm{T}}$ & Clay & $0.5-2.5$ & $\mathrm{MN} / \mathrm{m}^{2}$ & $<20$ \\
\hline & $\mathrm{q}_{\mathrm{c}}$ & Clay & $0.5-2$ & $\mathrm{MN} / \mathrm{m}^{2}$ & $20-40$ \\
\hline & $\mathrm{q}_{\mathrm{c}}$ & Sand & $0.5-30$ & $\mathrm{MN} / \mathrm{m}^{2}$ & $20-60$ \\
\hline VST & $\mathrm{S}_{\mathrm{u}}$ & Clay & $5-400$ & $\mathrm{kN} / \mathrm{m}^{2}$ & $10-40$ \\
\hline \multirow[t]{4}{*}{ SPT } & $\mathrm{N}$ & Clay and Sand & $10-70$ & blows/ft & $25-50$ \\
\hline & A reading & Clay & $100-450$ & $\mathrm{kN} / \mathrm{m}^{2}$ & $10-35$ \\
\hline & A reading & Sand & $60-1300$ & $\mathrm{kN} / \mathrm{m}^{2}$ & $20-50$ \\
\hline & $\mathrm{B}$ reading & Clay & $500-880$ & $\mathrm{kN} / \mathrm{m}^{2}$ & $10-35$ \\
\hline \multirow[t]{5}{*}{ DMT } & $\mathrm{B}$ reading & Sand & $350-2400$ & $\mathrm{kN} / \mathrm{m}^{2}$ & $20-50$ \\
\hline & $\mathrm{I}_{\mathrm{D}}$ & Sand & $1-8$ & & $20-60$ \\
\hline & $\mathrm{K}_{\mathrm{D}}$ & Sand & $2-30$ & & $20-60$ \\
\hline & $\mathrm{E}_{\mathrm{D}}$ & Sand & $10-50$ & $\mathrm{MN} / \mathrm{m}^{2}$ & $15-65$ \\
\hline & $\mathrm{P}_{\mathrm{L}}$ & Clay & $400-2800$ & $\mathrm{kN} / \mathrm{m}^{2}$ & $10-35$ \\
\hline \multirow[t]{5}{*}{ PMT } & $\mathrm{P}_{\mathrm{L}}$ & Sand & $1600-3500$ & $\mathrm{kN} / \mathrm{m}^{2}$ & $20-50$ \\
\hline & $\mathrm{E}_{\text {PMT }}$ & Sand & $5-15$ & $\mathrm{MN} / \mathrm{m}^{2}$ & $15-65$ \\
\hline & $\mathrm{w}_{\mathrm{n}}$ & Clay and silt & $13-100$ & $\%$ & $8-30$ \\
\hline & $\mathrm{w}_{\mathrm{L}}$ & Clay and silt & $30-90$ & $\%$ & $6-30$ \\
\hline & $\mathrm{w}_{\mathrm{p}}$ & Clay and silt & $15-15$ & $\%$ & $6-30$ \\
\hline \multirow[t]{4}{*}{ Lab Index } & PI & Clay and silt & $10-40$ & $\%$ & $-^{\mathrm{a}}$ \\
\hline & LI & Clay and silt & 10 & $\%$ & $-{ }^{\mathrm{a}}$ \\
\hline & $\gamma, \gamma_{\mathrm{D}}$ & Clay and silt & $13-20$ & $\mathrm{kN} / \mathrm{m}^{3}$ & $<10$ \\
\hline & $\mathrm{D}_{\mathrm{r}}$ & Sand & $30-70$ & $\%$ & $10-40 ; 50-70^{\mathrm{b}}$ \\
\hline
\end{tabular}

Notes: ${ }^{\mathrm{a}} \mathrm{COV}=\left(\overline{3-1.2 \%) / \text { mean, }}{ }^{\mathrm{b}}\right.$ The first range of variables gives the total variability for the direct method of determination, and the second range of values gives the total variability for the indirect determination using SPT values.

In the absence of unlimited resources that would permit as many boreholes and tests as needed, geotechnical engineers find themselves most of the time having to deal with limited site investigation data. The traditional approach in dealing with limitation in design has been to use characteristic values of the soil properties combined with a factor of safety. However, for a particular soil layer, soil parameter data sampled at multiple locations on a site would likely plot in a bell-shaped curve. This variability, even in the smallest of sites, suggests that geotechnical engineering systems are amenable to a statistical approach, and most soil properties can be regarded as random variables conforming to the "normal" or "Gaussian" theoretical distribution, thus established statistical methods based on the normal distribution may safely be applied in estimating design parameters (Fenton \& Griffiths, 2008; Lumb, 1966).

\section{Field Data Collection and Processing}

To achieve the main objective of this study, it was important to investigate and understand the spatial distribution of soil properties and levee characteristics in a select geographical area. In this research the dependent variables were selected to be the soil type (e.g. sand, clay, silt) and its associated properties (e.g. shear strength and unit weight). Independent variables were selected, based on theory and engineering judgment, to correlate with the dependent variables and then applying a geostatistical kriging approach to estimate the dependent variable's spatial distribution. The underlying geology and river geomorphology in the study area have played an important role in identifying these variables in this research project. Geomorphology is by definition the study of landforms, such as naturally formed levees, and the history of formation and dynamic processes that shape them.

A pilot study area was selected so that the previously described variables and correlations could be studied and analyzed. The study area used for this research encompasses the levee system protecting Sacramento City as well as the Feather River, both situated at the northeastern limit of the San Joaquin-Sacramento delta region, where the levee material and cross-sections can be considered typical of the area. A possible earthquake related levee 
system failure in Sacramento alone, as per one estimate, might put at risk more than 400,000 people and 170,000 structures, and have a potential economic impact of $\$ 7$ to $\$ 15$ billion (Hess et al., 2006). The study area is representative of the larger region constituting the greatest population density in Northern California and carrying more than $25 \%$ of the nation's annualized risk (FEMA, 2008). The specific areas used for data analysis and model development in this study were sub-sections of the larger SRFCP (Figure 3) grouped as:

(1) City of Sacramento, comprising of: West Sacramento region and American River.

(2) Feather River, comprising of: Feather River South and Reclamation District 784, City of Marysville and Feather River North.

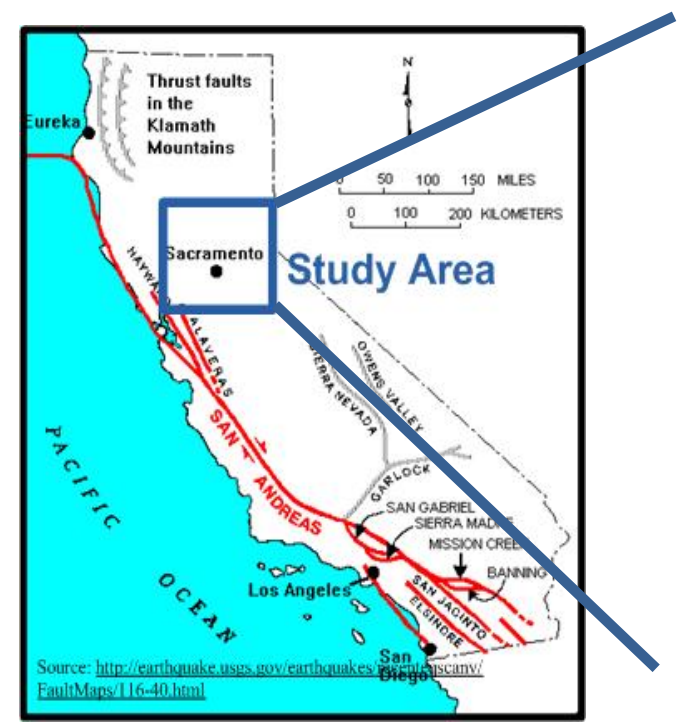

(A)

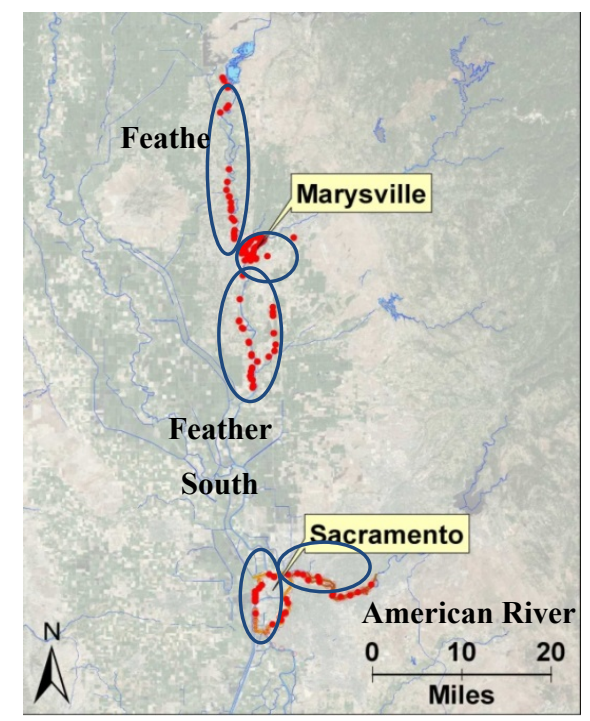

(B)

Figure 3. (A) Location of the study area in the state of California, with (B) close up view and details of the locations of available geotechnical investigation boreholes around Cities of Sacramento and Marysville

Data used for this study was collected from a number of sources (Table 2). Due to the spatial distribution of the data, the Geographic Information Systems (GIS) platform was used for reporting and analysing the data. Some of the spatial data was available from online databases such as the United States Geological Survey's Natural Map Viewer (USGS, 2010). Other data was not available in GIS format, especially data related to geotechnical investigation and levee layouts, and had to be manually digitized.

Table 2. Data types and sources

\begin{tabular}{ll}
\hline Data & Source \\
\hline Surface soil data & Soil Survey Geographic Database - SSURGO \\
Underlying geology features & United States Geological Survey - USGS \\
Hydrological features \& characteristics & National Hydrography Dataset - NHD \\
Ground water table & National Water Information System -USGS \\
Terrain elevation data & National Elevation Dataset - NED \\
County limit, cities, and road networks & State, county, and city authorities \\
Population & US Census Bureau \\
Land Cover & Multi-Resolution Land Characterization -MRLC \\
Aerial maps & Bing maps, through the ArcGIS online Server \\
& - Soil report for Sacramento City, US Army Corps of Engineers, 1987 \\
Levee geometry and soil properties & - Maps and borehole, URS Corporation and the California Department \\
& of Water Resources Urban Levee Evaluation Program, 2010 \\
\hline
\end{tabular}


The levee system is defined as the collection of earthen embankments with a corresponding delineated protected area. The levee system is divided for analysis purposes into segments called levee reaches. Levee reaches can be modeled based on the distribution of levee sections of similar embankment and foundation characteristics.

The underlying foundation geology below the river bed of the Sacramento River in California, according to Helley and Harwood (1985), is detailed in Table 3. Manual tracing of the area limits was done using scanned hand-drawn USGS maps and GIS geo-referencing and editing tools resulting in Figure 4.

Table 3. Underlying geology classification for the Sacramento River basin

\begin{tabular}{|c|c|c|c|c|}
\hline $\begin{array}{l}\text { Deposit } \\
\text { Classification }\end{array}$ & Code & Short Description & $\begin{array}{l}\text { Geological } \\
\text { Epoch }\end{array}$ & $\begin{array}{l}\text { Maximum } \\
\text { Thickness (m) }\end{array}$ \\
\hline $\begin{array}{l}\text { Alluvial } \\
\text { Deposits }\end{array}$ & Qa & Alluvium - Unweathered gravel, sand, \& silt & Holocene & 10 \\
\hline $\begin{array}{l}\text { Basin } \\
\text { Deposits }\end{array}$ & Qb & $\begin{array}{l}\text { Basin Deposits, Undivided - Fine grained silt \& } \\
\text { clay }\end{array}$ & Holocene & 60 \\
\hline $\begin{array}{l}\text { Alluvial } \\
\text { Deposits }\end{array}$ & Qsc & $\begin{array}{l}\text { Stream Channel Deposits of open, active stream } \\
\text { channels (morphology constantly changing) }\end{array}$ & Holocene & 25 \\
\hline $\begin{array}{l}\text { Alluvial } \\
\text { Deposits }\end{array}$ & Qmu & $\begin{array}{l}\text { Modesto Formation - Upper Member - } \\
\text { Unconsolidated, unweathered mix of gravel, } \\
\text { sand, silt and clay }\end{array}$ & Pleistocene & 120 \\
\hline $\begin{array}{l}\text { Alluvial } \\
\text { Deposits }\end{array}$ & Qml & $\begin{array}{l}\text { Modesto Formation - Lower Member - } \\
\text { Unconsolidated, slightly weathered gravel, } \\
\text { sand, silt, \& clay }\end{array}$ & Pleistocene & 120 \\
\hline $\begin{array}{l}\text { Alluvial } \\
\text { Deposits }\end{array}$ & Qru & $\begin{array}{l}\text { Riverbank Formation - Upper Member - } \\
\text { Unconsolidated alluvium composed of gravel, } \\
\text { sand and silt }\end{array}$ & Pleistocene & 120 \\
\hline $\begin{array}{l}\text { Alluvial } \\
\text { Deposits }\end{array}$ & Qrl & $\begin{array}{l}\text { Riverbank Formation - Lower Member - } \\
\text { Semiconsolidated gravel, sand, \& silt }\end{array}$ & Pleistocene & 120 \\
\hline $\begin{array}{l}\text { Alluvial } \\
\text { Deposits }\end{array}$ & Qsc & $\begin{array}{l}\text { Stream Channel Deposits of open, active stream } \\
\text { channels (morphology constantly changing) }\end{array}$ & Holocene & 250 \\
\hline
\end{tabular}

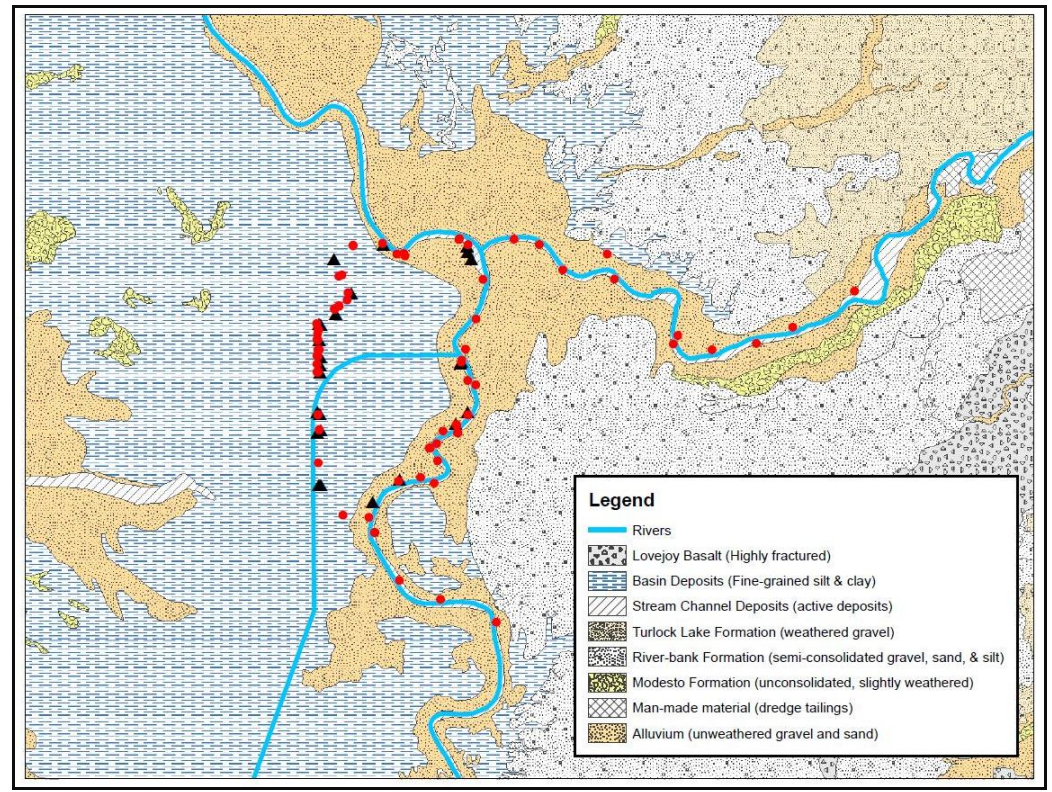

Figure 4. Underlying foundation geology regions drawn in ArcGIS reflecting the hand-drawn maps prepared by Helley and Harwood (1985) 
A river's sinuosity is its tendency to meander back and forth across the floodplain over time, in what looks like an S-shaped pattern (Figure 5A). Mount (1995) states that the scarcity of "perfectly straight" rivers in nature is widely believed to indicate that meandering is the more preferred state of single channel rivers. The development of sinuosity in a river takes place due to secondary flow (flow that moves downstream in a cylindrical spiral motion within the channel). The longitudinal bed profile of most rivers is divided into series of alternating high and low gradient segments. This results in the formation of riffles (high points on bed profile) and pools (deep water areas between riffles). In a low-sinuosity low-gradient channel, the overall stream power is usually low, the secondary flow minimal, and thus there is little erosion of the banks and the channel remains relatively static. However, when stream power is great enough, bank erosion will increase initiating the formation of meander bends. Increased meandering and outer bank erosion is matched by increased deposition of material on the opposite bank resulting in alternating point bars along the river length (Figure 5B). A result of the above described process a "relatively straight" river section is expected to have less variability in the properties of the material deposited at its banks than a section that is "meandered".

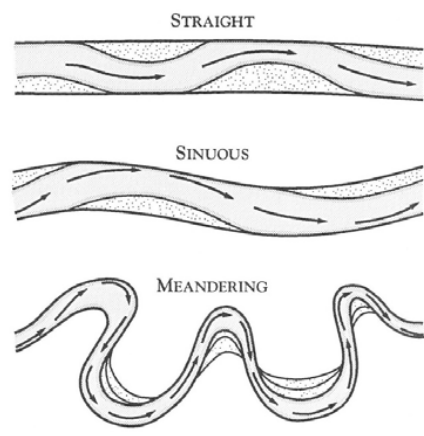

(A)

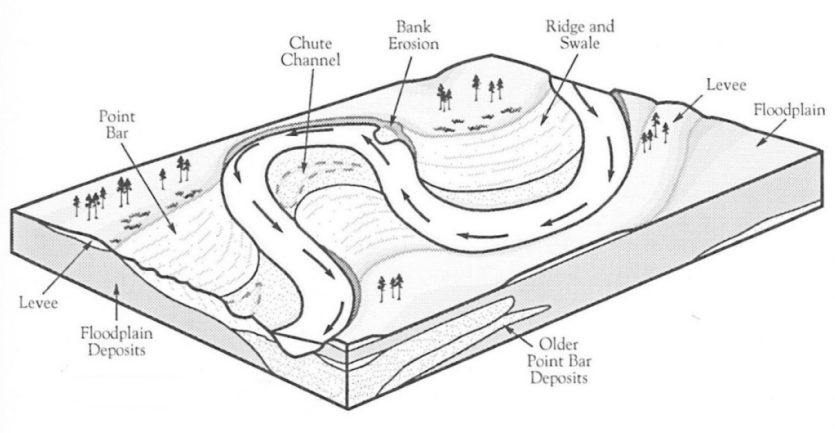

(B)

Figure 5. (A) Different levels of river meandering, with arrows indicating location of highest velocity flows and (B) major sedimentary features of a meandering single channel river, showing erosion and deposition process leading to formation of point bars (Mount, 1995)

The meander ratio, or Sinuosity Index, SI, is a means of quantifying how much a river or stream meanders. It measures the deviation of a river center path length from the shortest possible path, and is a reflection of the channel length required to cover a given point-to-point straight line distance. SI is calculated as the length of the river channel center path divided by the straight line length of the valley containing the river. In straight streams, $\mathrm{SI}=1.0$, whereas a value of 4.0 is considered to be highly intricate meandering. For this study, and based on classifications by researchers in the field (Gordon et al., 2004; Mueller, 1968) the scale shown in Table 4 was adopted.

Table 4. Level of river meandering as a function of the Sinuosity Index, SI

\begin{tabular}{ll}
\hline Sinuosity Index, SI & Level of Meandering \\
\hline $1.0-1.1$ & Straight \\
$1.1-1.3$ & Sinuous \\
$1.3-1.5$ & Slightly meandering \\
$>1.5$ & Meandering \\
\hline
\end{tabular}

In order to calculate SI, it is necessary first to define the length of "one meander wave", L, similar to the concept of the frequency of a sinusoid wave function (Figure 6). A number of authors (Julien, 2002; Thorne et al., 1997) refer back to the work by Leopold et al. (1964) who found that meander wave length (L) varies from $\mathrm{L}=$ $7.32 \mathrm{w} 1.1$ to $12.13 \mathrm{w} 1.09$ with the average roughly equal to 10 times the river channel width "w". No streams existing in nature owe all of their sinuosity to hydraulic factors, rather, almost all streams have some degree of both hydraulic and topographic sinuosity (Mueller, 1968). However, for simplicity, it is common to derive the SI based on concepts of hydraulics. 


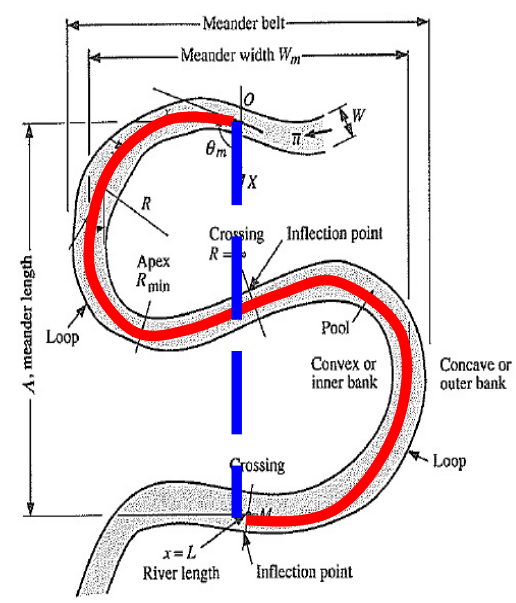

Figure 6. Characterization of a meandering river (Julien, 2002). The Sinuosity index is derived by dividing the river length (solid line), L, by the straight line valley length (dashed line)

A number of meander wave lengths, referred to as river segmentation levels, were applied at the study areas in order to come up with values of SI. The river features are divided into segments, each equal to the segmentation levee of interest, and the calculated value of the Sinuosity Index is assigned to the individual segments (Figure 7). For the Sacramento City area, the river width varied from $\sim 70$ to $\sim 210 \mathrm{~m}$, with most river segments widths around the value of $150 \mathrm{~m}$, giving a rough estimate of the expected meander length of $1,500 \mathrm{~m}$. Using the above mentioned equations by Leopold et al. (1964) the segmentation levels tried for Sacramento were $500 \mathrm{~m}, 1500 \mathrm{~m}$, $1750 \mathrm{~m}, 2500 \mathrm{~m}$, and $3500 \mathrm{~m}$. For Feather River, the width varied from $\sim 60$ to $\sim 150 \mathrm{~m}$, with most river segments widths around the value of $100 \mathrm{~m}$, giving a rough estimate of the expected meander length of $1,000 \mathrm{~m}$. The segmentation levels tried in this area were $500 \mathrm{~m}, 1000 \mathrm{~m}, 1500 \mathrm{~m}$, and $2500 \mathrm{~m}$.
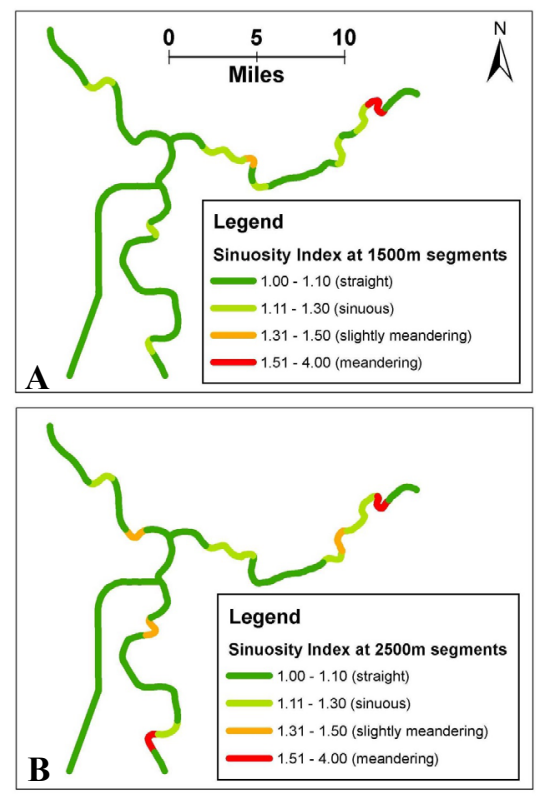

Figure 7. Comparison of Sinuosity Index output for different river segmentation levels at Sacramento City: (A) segmentation level of $1,500 \mathrm{~m}$ and (B) segmentation level of $2,500 \mathrm{~m}$

The issue of sinuosity is further complicated by having single vs. multiple parallel river channels. Because of lateral migration of meandering streams, levees should be placed at a fair distance from migrating channels (Julien, 2002). However, this is not always the case, especially in urban areas where insufficient space forces the building of levees at the edge of the stream. Thus it becomes important to determine the levee parts located in the 
highly meandered river sections in order to give them special attention in the analyses. Sacramento River is a meandering single-channel river that occupies one relatively stable main channel surrounded by an extensive floodplain. It is a prime example of meandering river, although channeling by public works projects has greatly altered the original pattern of such rivers (Mount, 1995).

The ground water table level in the study areas was determined because of its direct effect on the calculation of effective stress values in soil. The results of all calculated groundwater level, from data covering the period from 1983 to 2010 (USGS, 2011), are summarized in Table 5, and are in agreement with measurements available from the USACE report (USACE, 1987).

Table 5. Calculated ground water table (GWT) levels $(\mathrm{m})$ in the study area, Mean Sea Level=0m

\begin{tabular}{lccccccc}
\hline \multirow{2}{*}{ Area } & \multicolumn{2}{c}{ Elevation $(\mathrm{m})$ from MSL } & & \multicolumn{2}{c}{ Relative Depth $(\mathrm{m})$} \\
\cline { 2 - 3 } \cline { 7 - 7 } & Crest & Toe & GWT & & GWT below Crest & GWT below Toe \\
\hline Feather River North & 30 & 25 & 15 & & 15 & 10 \\
Marysville & 27 & 21 & 12 & & 15 & 13 & 9 \\
Feather River South \& RD784 & 22 & 15 & 9 & & 12 & 6 \\
Sacramento City & 12 & 6 & 0 & & 6 \\
\hline
\end{tabular}

\section{Geotechnical Investigation Data}

As previously mentioned, geotechnical soil investigation data for the study area was collected from (1) URS corporation data from the California Urban Levee Evaluation Project (URS, 2010) and (2) the USACE investigation report for Sacramento City (1987). Data from both sources included levee layout, levee geometry, boreholes logs and field tests. The total number of available logs, CPTs, and reported tests are summarized in Tables 6 and 7. All boreholes were digitized into a GIS format, and available test information extracted for further analysis. Note that a large number of historical boreholes were reported in the URS dataset. No test results were available for these, and they were short-listed and only used in the process of identifying regional stratigraphy.

Laboratory test data reported in the URS database included Consolidated Undrained Strength (CU) and Vane Shear (VS) testing. However, the numerical values of these tests were not provided. Other lab test results included Water Content (WC), Liquid Limit (LL), Plasticity Index (PI), and Fines Content (\%).

CPT data was validated through close comparison to nearby borehole logs for soil layer delineation and soil classification. Subsequently, resulting common site specific CPT "signatures" (Figure 8) were developed for areas with no boreholes.

CPT cone tip resistance was used to determine Undrained Shear Strength $(\mathrm{Su})$ of cohesive soils. The following empirical correlation (Lunne et al., 1997) was used (Equation 1):

$$
\mathrm{Su}=\left(\mathrm{q}_{\mathrm{t}}-\sigma_{\mathrm{vo}}\right) / \mathrm{N}_{\mathrm{kt}}
$$

where $\mathrm{q}_{\mathrm{t}}$ is the corrected cone resistance, $\mathrm{N}_{\mathrm{kt}}$ is an empirical cone factor, and $\sigma_{\mathrm{vo}}$ is the total in-situ vertical stress.

The empirical parameter $\mathrm{N}_{\mathrm{kt}}$ is site specific, and can be back-calculated using available triaxial compression test results (USACE, 1987). It is worth noting that for the same site, the value of $\mathrm{N}_{\mathrm{kt}}$ varies depending on the type of laboratory test used to determine Su (Lunne et al., 1997). Laboratory measured Su values from USACE boreholes in West Sacramento were paired with corresponding nearby clay layers (at similar depth) from the URS CPTs. The back-calculated $\mathrm{N}_{\mathrm{kt}}$ values had an average of 20.8 which is within, though at the high end of, ranges of $\mathrm{N}_{\mathrm{kt}}$ values reported in the literature (Lunne et al., 1997).

In order to derive friction angle, $\phi$, values for cohesionless soils, Standard Penetration Test (SPT) values (N and $\mathrm{N}_{60}$ ) had to be adjusted to $\mathrm{N}_{1,60}$ using required correction factors and effective stress calculations made possible by the determined ground water table levels. A number of approaches were used for estimating friction angle, $\phi$, values and are compared in Table 8. The friction angle in this study was derived from SPT using Kulhawy and Mayne (1990), and from Cone Penetration Test (CPT) results using Robertson and Campanella (1983). 
Table 6. Summary of available geotechnical investigation borehole logs and cone penetration tests (CPTs) in the study areas

\begin{tabular}{lllllllll}
\hline & \multicolumn{3}{c}{ URS Boreholes } & & URS Historical & USACE & URS CPTs \\
\hline Area & Borehole (B) & $\begin{array}{l}\text { Hollow Stem } \\
\text { Auger (A) }\end{array}$ & $\begin{array}{l}\text { Hand } \\
\text { Auger (H) }\end{array}$ & $\begin{array}{l}\text { Sonic } \\
\text { Core (S) }\end{array}$ & $\begin{array}{l}\text { Piezometer } \\
\text { (M) }\end{array}$ & Historical Log & Borehole & CPT \\
\hline West Sacramento & 26 & - & - & - & 4 & $9^{\text {a }}$ & 34 & 25 \\
American River & 10 & - & - & - & 6 & $27^{\text {a }}$ & - & - \\
Marysville & 49 & - & - & 4 & 16 & - & - & - \\
RD784 & 21 & - & - & 2 & - & - & - & - \\
Feather North & 10 & 14 & 5 & - & - & - & - & 19 \\
Feather South & 14 & $10^{\mathrm{b}}$ & 6 & - & - & - & - & 74 \\
Total & $\mathbf{2 6 7}$ & & & & & & & $\mathbf{1 1 8}$ \\
\hline Notes & & & & & & & &
\end{tabular}

${ }^{a}$ Many more available. These are a short list of historical boreholes used for this study.

b One borehole was "Solid" and not "Hollow" Stem Auger.

Table 7. Reported field and lab tests within the available geotechnical investigation boreholes and cone penetration tests (CPTs) in the study areas

\begin{tabular}{|c|c|c|c|c|c|c|c|c|c|c|c|c|c|}
\hline \multirow{2}{*}{ Area } & \multicolumn{9}{|c|}{ URS boreholes and USACE } & \multicolumn{4}{|c|}{ URS CPTs } \\
\hline & SPT & $\mathbf{M C}^{\mathrm{a}}$ & $\mathbf{C U}^{\mathrm{b}}$ & $\mathbf{V S}^{\mathbf{b}}$ & WC & $\mathbf{L L}$ & PI & Fines & $\mathbf{U U}^{\mathrm{c}}$ & $\mathbf{R f}^{\mathbf{d}}$ & $q^{t^{d}}$ & $\mathbf{f s}^{\mathrm{d}}$ & $\mathbf{u}_{2}{ }^{\mathrm{d}}$ \\
\hline West Sacramento & 648 & 46 & 11 & 2 & 173 & 166 & 166 & 298 & 30 & 25 & & & \\
\hline American River & 133 & 4 & - & - & 35 & 13 & 12 & 56 & - & - & & & \\
\hline Marysville & 651 & 19 & 15 & - & 39 & 35 & 35 & 90 & - & - & & & \\
\hline RD784 & 217 & 25 & 19 & - & 111 & 96 & 96 & 158 & - & - & & & \\
\hline Feather North & 211 & 2 & 7 & - & 27 & 25 & 25 & 81 & - & 19 & & & \\
\hline Feather South & 233 & - & 22 & - & 93 & 84 & 84 & 123 & - & 74 & & & \\
\hline Total & 2093 & & & & 478 & 419 & 418 & 806 & 30 & & & & \\
\hline
\end{tabular}

Notes

${ }^{\text {a }}$ Modified California test numbers to be converted to SPT equivalent.

${ }^{\text {b }}$ Numerical results for Consolidated Undrained (CU) triaxial tests and Vane Shear (VS) tests were not provided.

${ }^{\mathbf{c}}$ Unconsolidated Undrained (UU) triaxial tests were only available from the USACE (1987) data.

${ }^{\mathrm{d}} \mathrm{CPT}$ logs represent continuous measurement of parameters.

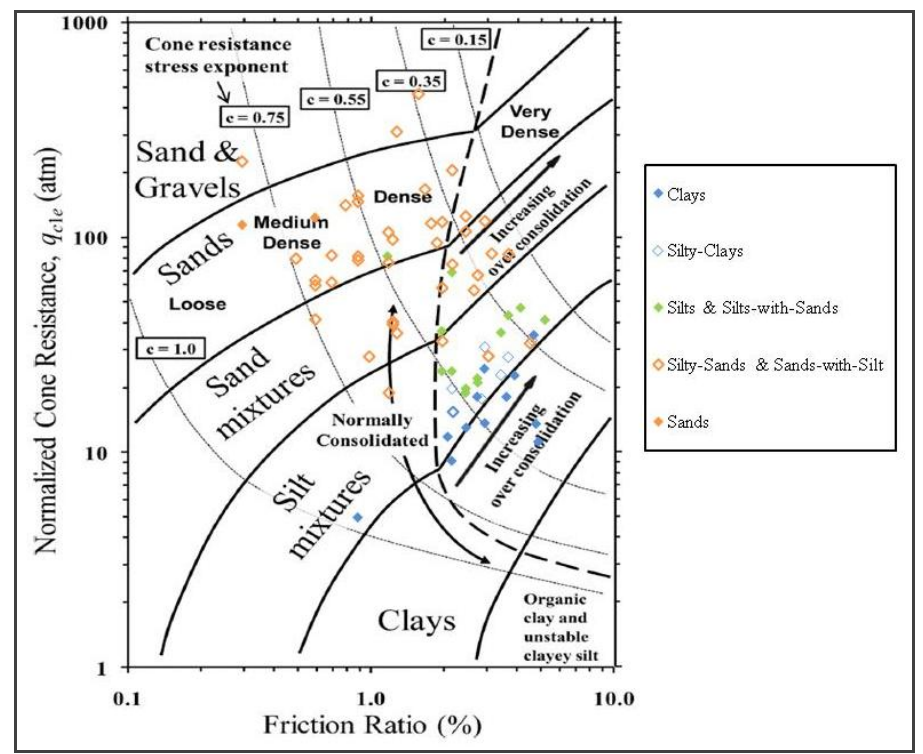

Figure 8. Example of collected CPT data from Sacramento City area plotted on the Olsen and Mitchell (1995) soil classification chart 


\section{Prediction of Regional Soil Stratigraphy}

Prior to estimating the spatial variability of soil parameters, there is a need to estimate the soil stratigraphy in the area of study. Due to the increased uncertainties in derivation of strength parameters from in-situ tests for silts, the focus was to determine the stratigraphy of sands and clays, since the derivation of strength parameters for those two categories of soils was possible given the available data. Therefore, a general category of "Sand" was adopted for soils classified, according to the Unified Soil Classification System USCS (ASTM, 2011), as Poorly graded Sand (SP), Well-graded sand (SW), Poorly-graded Sand with Silt i.e. $5 \%<\%$ Fines $<12 \%$ (SP-SM) and Well-graded Sand with Silt i.e. 5\%<\% $<$ Fines $<12 \%$ (SW-SM). Similarly, a general category of "Clay" was adopted for soils classified as Fat Clay (CH), Lean Clay (CL) and Silty Clay (CL-ML), according to USCS.

Furthermore, because of the geostatistical complexity of combining both the estimation of thickness variation of different layer types (qualitative parameter), with the estimation of the soil parameter variability within each layer (quantitative parameter), and because the focus of this research was the study of soil properties variability, soil layers were assumed to exist at a constant thickness throughout the study areas. For each of the two study areas (Sacramento and Feather River), and based on the available borehole log classifications, plots were developed to help identify the stratigraphy of the region. These plots do not include material identified as engineering fill within the levee, as the intent of the research is to study the spatial variation of naturally occurring soils. The plots also confirm that, within the area of study, the regional stratigraphy can be assumed to be uniform for the scope of this research. The layer delineation is determined based on the number of data points occurring with depth, in combination with the layer thickness for each data point in the respective borehole log. The "layer range" value for each identified layer represents the thickness of the band of soil where the identified layer was observed. The delineation of clay layers takes into account the corresponding delineation of the sand layers, and vice versa. As an example, Figure 9 shows the approach used for the delineation of layers in the Sacramento area based on available boreholes from USACE and URS datasets. The layers identified in Sacramento from Figure 9 are listed in Table 9. Similarly the resulting layer delineation for Feather River was performed using the URS boreholes, and the results are presented in Table 10. The number of layers observed was dependent on the limitation of depth of boreholes.

The following steps have been applied to all layers of both study areas. However, only figures relating to the identified "Shallow Clay layer in Sacramento" (the top layer in Figure 9) will be used as examples in the coming sections.

\section{Prediction of Spatial Variability of Soil Parameters}

\subsection{Correlation of Soil Parameters to Regional Factors}

For the delineated layers of clay and sand, the soil parameters that were studied were, for Sands: Friction Angle $(\phi)$ and Fines Content (\%), and for Clays: Undrained Shear Strength (Su), Liquid Limit (LL), Plasticity Index (PI), and Ratio of Water Content to Liquid Limit (WC/LL).
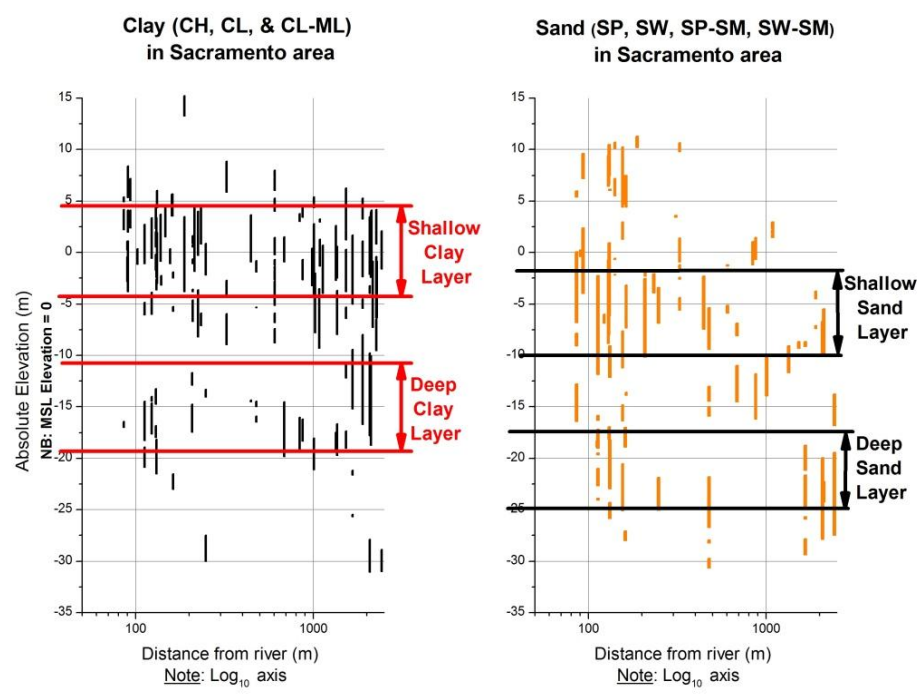

Figure 9. Process of layers delineation for clay and sand in Sacramento based on borehole log information 
Table 8. Delineation of Clay and Sand layers in Sacramento area

\begin{tabular}{|c|c|c|c|c|c|c|c|}
\hline \multirow{2}{*}{ Location } & \multirow{2}{*}{ Material } & \multirow{2}{*}{ Depth } & \multirow{2}{*}{ Depth order } & \multirow{2}{*}{ Layer ref. } & \multicolumn{3}{|c|}{ Absolute Elevation (m) MSL $=0$} \\
\hline & & & & & From & To & Layer Range \\
\hline \multirow{4}{*}{ Sacramento City } & Clay & shallow & 1 & 1st Clay & 4 & -4 & 8 \\
\hline & Sand & shallow & 2 & 1st Sand & -2 & -10 & 8 \\
\hline & Clay & deep $^{a}$ & 3 & 2nd Clay & -11 & -19 & 8 \\
\hline & Sand & deep $^{a}$ & 4 & 2nd Sand & -18 & -25 & 7 \\
\hline
\end{tabular}

Note: ${ }^{\mathrm{a}}$ Data available only from West Sacramento URS dataset.

Table 9. Delineation of clay and sand layers in feather river area

\begin{tabular}{|c|c|c|c|c|c|c|c|}
\hline \multirow{2}{*}{ Location } & \multirow{2}{*}{ Material } & \multirow{2}{*}{ Depth } & \multirow{2}{*}{ Depth order } & \multirow{2}{*}{ Layer ref. } & \multicolumn{3}{|c|}{ Absolute Elevation (m) MSL $=0$} \\
\hline & & & & & From & To & Layer Range \\
\hline Feather South \& RD784 & & & & & 17 & 10 & 7 \\
\hline Marysville & Clay & shallow & 1 & 1st Clay & 22 & 13 & 9 \\
\hline Feather North & & & & & 25 & 17 & 8 \\
\hline Feather South \& RD784 & & & & & 11 & 6 & 5 \\
\hline Marysville & Sand & shallow & 2 & 1st Sand & 15 & 8 & 7 \\
\hline Feather North & & & & & 20 & 12 & 8 \\
\hline Feather South \& RD784 & & & & & 7 & 0 & 7 \\
\hline Marysville & Clay & deep & 3 & 2nd Clay & 7 & 0 & 7 \\
\hline Feather North & & & & & 12 & 6 & 6 \\
\hline
\end{tabular}

The parameters were analyzed and correlations were developed, where applicable, with regional factors including distance to closest river, sinuosity of closest river segment, and underlying geology classification. The concept of "Effective Correlation Distance" between the soil parameters and the factors was introduced, representing the distance beyond which no trend/correlation was observed or deemed physically significant. Figure 10 is shown, as an example, for the shear strength parameter $\mathrm{Su}$ of the Sacramento area allow clay layer. Tables 11 and 12 show the established "Effective Correlation Distance" and the "Sinuosity Index Segmentation Level" for all seven layers. The latter is a reflection of the river meander length period.

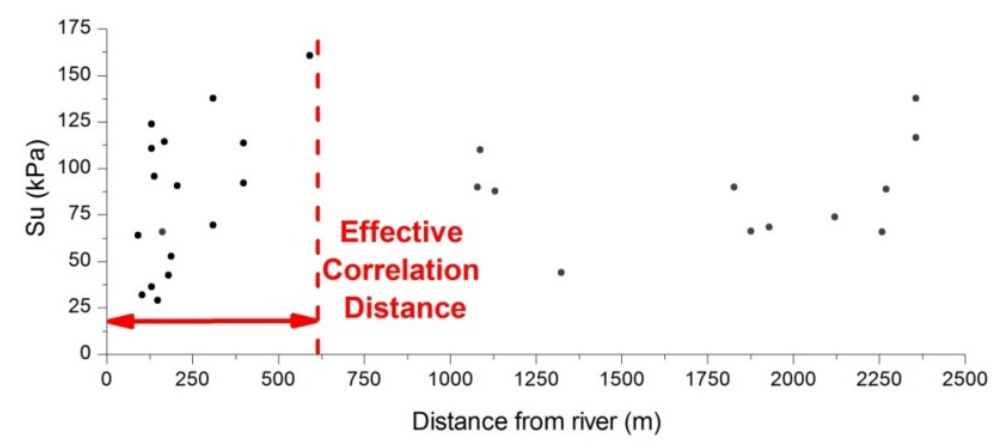

Figure 10. Example of determination of the "Effective Correlation Distance" for the shear strength parameter, $\mathrm{S}_{\mathrm{u}}$, for the Sacramento area shallow clay layer 
Table 10. "Effective Correlation Distance" and "Sinuosity Index Segmentation Level" for soil layers in Sacramento area

\begin{tabular}{lllllllllll}
\hline \multirow{2}{*}{ Location } & \multirow{2}{*}{ Material } & \multirow{2}{*}{ Depth } & \multicolumn{2}{c}{ SI segmentation level $(\mathbf{m})$} & \multicolumn{6}{c}{ Effective correlation distance $(\mathbf{m})$} \\
\cline { 6 - 9 } & & & & $\boldsymbol{\phi}$ & Fines & $\mathbf{S}_{\mathbf{u}}$ & $\mathbf{L L}$ & PI & WC/LL \\
\hline \multirow{3}{*}{ Sacramento City } & shallow & 1750 & - & - & 600 & 600 & 600 & 1500 \\
& Sand & shallow & 1750 & 450 & 450 & - & - & - & - \\
& Clay & deep & 1750 & - & - & $\mathrm{n} / \mathrm{a}^{\mathrm{a}}$ & 1500 & 1500 & 1500 \\
& Sand & deep & 1750 & 450 & 450 & - & - & - & - \\
\hline
\end{tabular}

Note: a Only three data points, and all are at large distance from the river.

Table 11. "Effective Correlation Distance" and "Sinuosity Index Segmentation Level" for soil layers in Feather River area

\begin{tabular}{|c|c|c|c|c|c|c|c|c|c|}
\hline \multirow{2}{*}{ Location } & \multirow{2}{*}{ Material } & \multirow{2}{*}{ Depth } & \multirow{2}{*}{$\begin{array}{l}\text { SI segmentation } \\
\text { level }(\mathrm{m})\end{array}$} & \multicolumn{6}{|c|}{ Effective correlation distance (m) } \\
\hline & & & & $\phi$ & Fines & $\mathbf{S}_{\mathbf{u}}$ & $\mathbf{L L}$ & PI & WC/LL \\
\hline \multirow{3}{*}{ Feather River } & Clay & shallow & 1000 & - & - & 600 & 600 & 600 & 600 \\
\hline & Sand & shallow & 1000 & 450 & 450 & - & - & - & - \\
\hline & Clay & deep & 1000 & - & - & $600^{\mathrm{a}}$ & $600^{\mathrm{a}}$ & $600^{\mathrm{a}}$ & $600^{\mathrm{a}}$ \\
\hline
\end{tabular}

Note: ${ }^{a}$ Data available only from Feather River South.

Figure 11 summarizes the plots of the shallow Clay layer parameters ( $\mathrm{Su}, \mathrm{LL}, \mathrm{PI}, \mathrm{WC} / \mathrm{LL}$ ) in Sacramento in relation to the distance from the centerline of closest river segment. A further analysis of the particular relation between Su with geology (Figure 12) and Sinuosity Index (Figure 13) helps to establish preliminary relationships. For example, the latter figure implies that the value of $\mathrm{Su}$ decreases with increased river sinuosity. The $\mathrm{X}$-axis values in Figure 12, representing geology, are categorical values, thus no trend or fit can be deduced, but rather variability of Su parameter with each particular geology type is establish (Table 3).
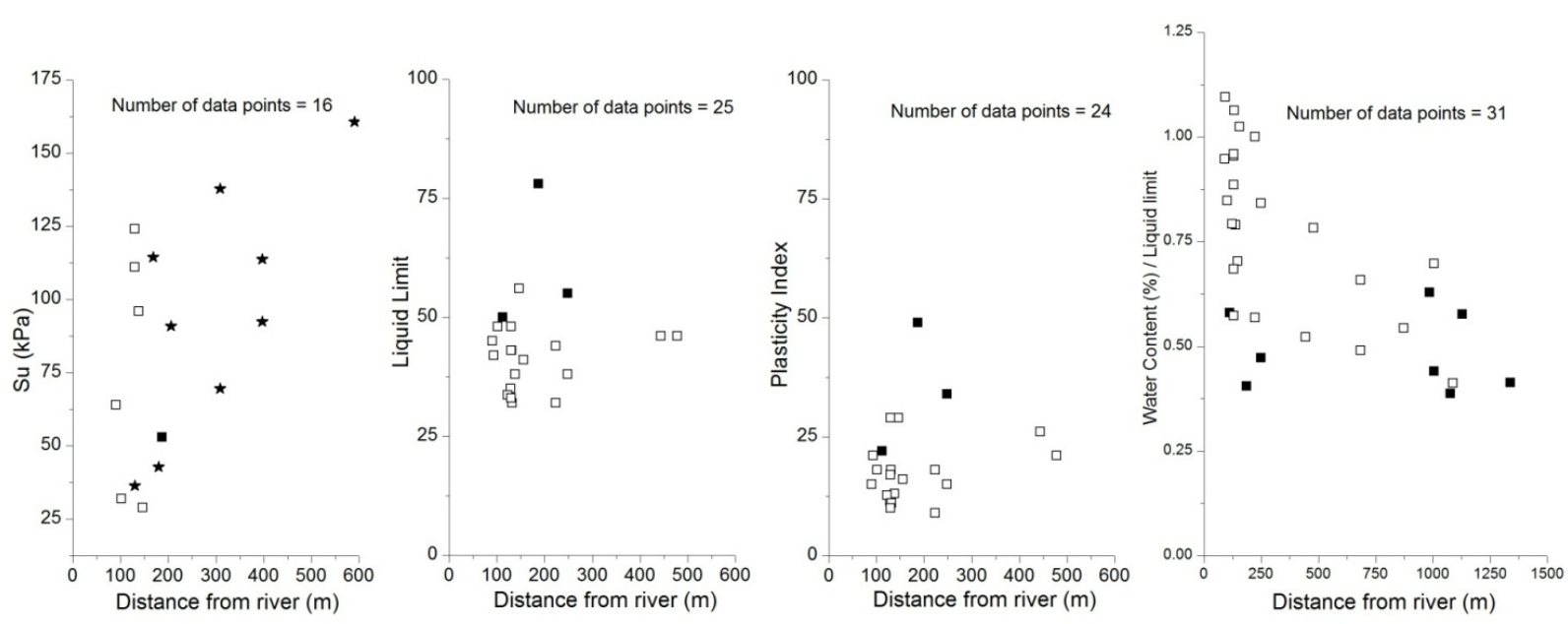

$$
\begin{aligned}
& \text { Su from USACE } 1987 \text { report triaxial compression lab testing } \\
& \text { - CH: Fat Clays } \\
& \square \quad \text { CL: Lean Clays } \\
& \text { Su derived from URS CPTs using a correlated value of Nkt=20 } \\
& \star \quad \text { Clays (as per Olsen \& Mitchell classification charts) }
\end{aligned}
$$

Figure 11. Relation of shallow clay soil parameters to distance from centerline of closest river segment in Sacramento 


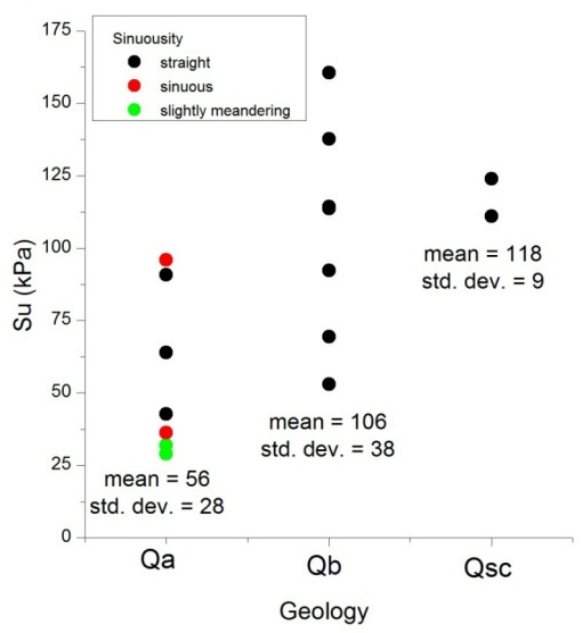

Qa: ALLUVIUM (Holocene)

- Unweathered gravel, sand, and silt

Qb: BASIN DEPOSITS (Holocene)

- Fine Grained Silt and Clay

Qsc: Stream Channel Deposits (Holocene)

- Deposits of open, active stream channels

Figure 12. Relation of $\mathrm{S}_{\mathrm{u}}(\mathrm{kPa})$ shallow clay soil parameter in Sacramento, to geology, categorized as per Sinuosity Index

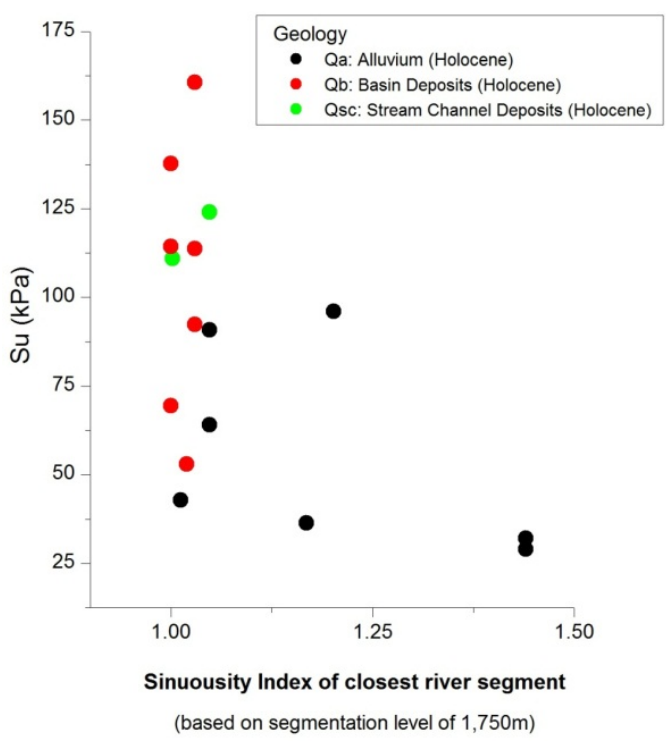

Figure 13. Relation of $\mathrm{S}_{\mathrm{u}}(\mathrm{kPa})$ shallow clay soil parameter in Sacramento, to Sinuosity Index, categorized as per regional geology

\subsection{Observations of Local vs. Regional Effects}

Clay in both shallow and deep, and in both areas of study, showed increasing trend of Su with increasing distance from river (Figure 14). Su values also increased with depth, which may be attributed to consolidation of the deeper layers over time. 

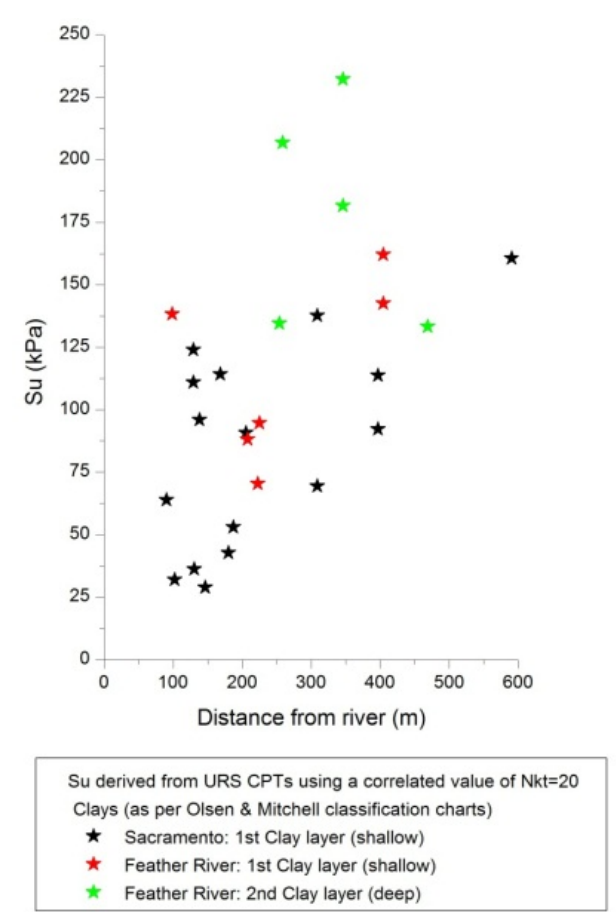

Figure 14. Relation of $\mathrm{S}_{\mathrm{u}}(\mathrm{kPa})$ soil parameter to distance from centerline of closest river segment, in Sacramento and Feather River for both shallow and deep layers of clay

As for relation of $\mathrm{Su}$ to the different geological formations in the two study areas (Figure 15), a general observation is that clay $\mathrm{Su}$ values in the areas of the Qa formation tend to have lower values than other areas. The Qa formation is defined as Alluvium - Unweathered gravel, sand, \& silt, as such clay is not the main component, which might provide an explanation for the lower values of Su for clay in these areas, as compared to other formations.

Figure 16 shows the observed Su relation to Sinuosity Index (SI). The higher number of data points at this low sinuosity level is due to the smaller number of river segments that are highly sinuous. An important observation across all areas of study, and at shallow and deep clay layers, is that Su tends to decrease with increasing sinuosity of the closest river segment. A possible explanation of this phenomenon is that deposition of fine particles tends to be more uniform (leading to higher $\mathrm{Su}$ values) if the river is less sinuous. Given the limited available data however, it should be noted that more data points are needed to develop more robust correlations between SI and shear strength or soil type. Furthermore, due to the specific case study area that was used, the limited data was primarily available for SI values close to 1 (i.e. straight river sections). Note that the Sinuosity is based on segmentation level of $1,750 \mathrm{~m}$ for Sacramento and $1,000 \mathrm{~m}$ for Feather River as discussed in section 3 . 


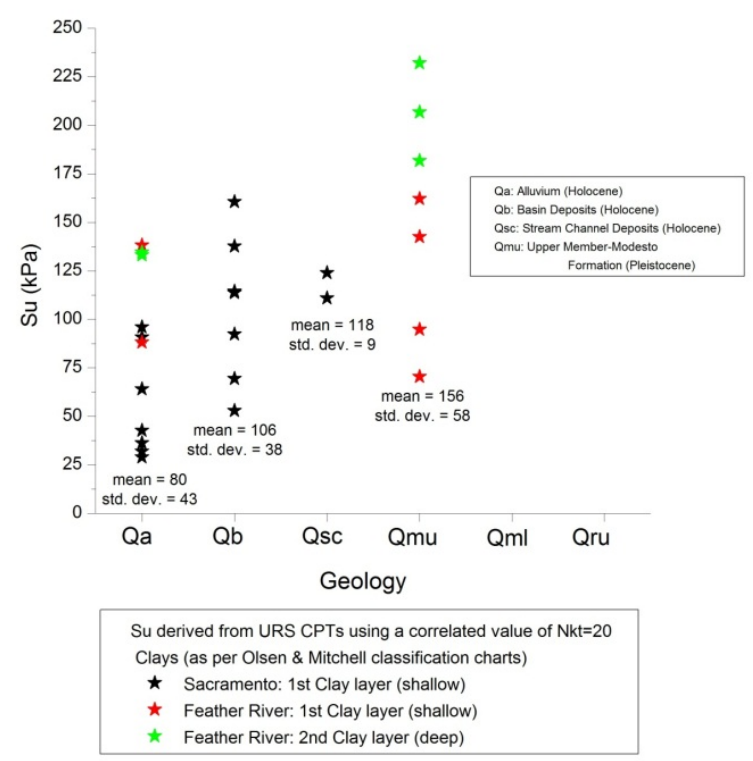

Figure 15. Relation of $\mathrm{S}_{\mathrm{u}}(\mathrm{kPa})$ soil parameter to geology, in Sacramento and Feather River for both shallow and deep layers of clay

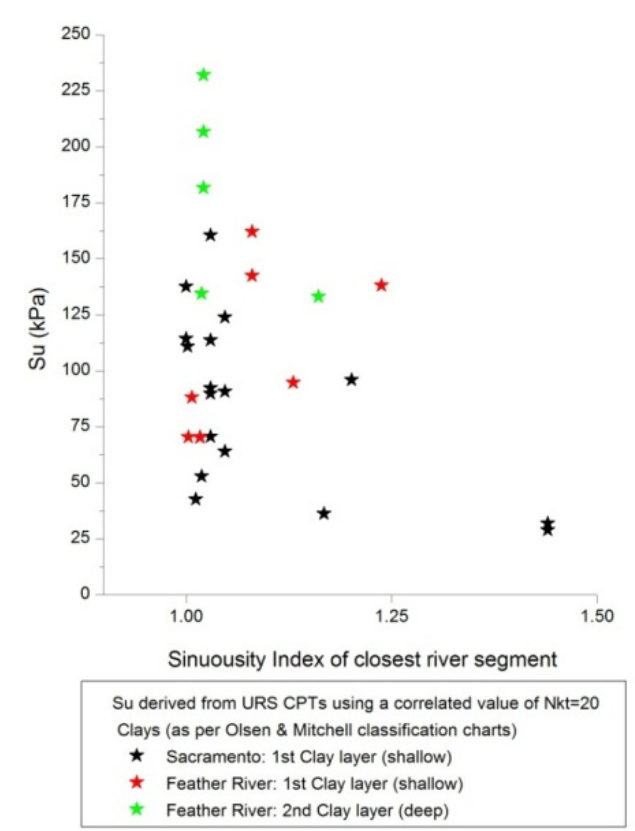

Figure 16. Relation of $\mathrm{S}_{\mathrm{u}}(\mathrm{kPa})$ soil parameter to Sinuosity Index, in Sacramento and Feather River for both shallow and deep layers of clay

\subsection{Kriging Estimation Using Measured Parameter Values}

The spatial variation of the soil strength parameters in the vicinity of levees was estimated by the ordinary kriging approach. The choice for ordinary kriging assumes that the local mean m(u) isn't necessarily closely related to the population (overall) mean and so only uses the samples (known values) in the local neighborhood of the estimate. The following steps demonstrate how to revise a spatially-based kriging (solely based on distance between known points) into a revised kriged map that reflects correlation of soil parameters with regional factors in the riverine environment of the Sacramento River basin.

Geostatistical analysis was performed using the ArcGIS Geostatistical Analyst software extension. Outputs of the geostatistical analysis of the known sampled data points include the empirical (or experimental) semi-variogram, cross-validation and error plots, as well as information pertaining to the main variables of interest at this stage: 
nugget, range, and sill. A summary of the range, nugget, and partial sill values from the semi-variograms is presented in Table 13. The "correlation range" is the distance beyond which no spatial relation exists between points, i.e. a known sampled points do not affect measurements at another point situated at this, or a larger, distance. The range value for clay is almost twice as large as the value for most sands. This is consistent with the observation that the effective correlation distance for clays was also larger than that of sand by a similar margin.

Table 12. Parameters from the ordinary kriging semi-variograms of identified soil layers in the study areas

\begin{tabular}{|c|c|c|c|c|c|c|c|}
\hline Location & Depth & Materi & Parameter & Unit & Correlation Range (m) & Nugget $^{a}$ & Partial Sill $^{\mathrm{a}}$ \\
\hline \multirow{4}{*}{ Sacramento City } & shallow & Clay & $\mathrm{S}_{\mathrm{u}}$ & $\mathrm{kPa}$ & 819 & 19.5 & 1730 \\
\hline & shallow & Sand & $\phi$ & degrees & 400 & 0.3 & 3 \\
\hline & deep & Clay & $\mathrm{S}_{\mathrm{u}}$ & $\mathrm{kPa}$ & $-\mathbf{b}$ & & \\
\hline & deep & Sand & $\phi$ & degrees & $177^{\mathrm{c}}$ & 1 & 17 \\
\hline \multirow{3}{*}{ Feather River } & shallow & Clay & $\mathrm{S}_{\mathrm{u}}$ & $\mathrm{kPa}$ & $-\mathbf{b}$ & & \\
\hline & shallow & Sand & $\phi$ & degrees & 407 & 1 & 11 \\
\hline & deep & Clay & $\mathrm{S}_{\mathrm{u}}$ & $\mathrm{kPa}$ & $-\mathbf{b}$ & & \\
\hline
\end{tabular}

Notes

a Units of these elements is the "square of the corresponding parameter unit".

${ }^{b}$ No Kriging estimate could be done due to limited number of data points available for the $S_{u}$ parameter of this layer.

${ }^{c}$ The low value of the range for the deep Sacramento River as compared to the other sand layers is due limited number of data points at large distances for this particular layer.

Kriging estimate maps were derived, with corresponding semi-variograms, for all identified layers in the study areas. A sample map output of the kriging approach for the estimation of the shear strength $\mathrm{Su}$ of the shallow foundation clay layer in Sacramento is shown in Figure 17, with shaded colour symbology representing variation of the estimated Su values, classified as: Soft to Medium Clay $(\mathrm{Su}<50 \mathrm{kPa})$, Stiff Clay $(50 \mathrm{kPa}<\mathrm{Su}<100 \mathrm{kPa}), \mathrm{Very}$ Stiff Clay $(100 \mathrm{kPa}<\mathrm{Su}<150 \mathrm{kPa})$, and Hard Clay $(\mathrm{Su}>150 \mathrm{kPa})$. The area between the dashed lines running parallel on both sides of the river represents the "Effective Correlation Distance" between the soil parameter and the factors. The focus is to estimate the soil variability in within this distance from the river because (1) correlation of soil strength parameters with regional factors has been established with this limitation, and (2) this distance is far enough from the levee in a way that the soil parameter values beyond that will not affect the response of the levee fill.

\subsection{Adjustment of Kriging Estimate Using Regional Correlations}

A uniform grid of points was established within the effective correlation area from the river center. At these grid locations the estimated kriging Su values were read, and adjusted as needed to reflect the correlations with regional factors. A large grid size would not capture the correlations with the regional factors, nor will it capture the effect of spatial auto-correlation of individual soil parameters, and a confirmation of the most effective grid size requires field validation of the estimated parameters. Each location on the grid is assigned the attributes of (1) Experimental Kriging estimate value (Figure 17), (2) Distance to closest segment of river, (3) Geology layer, and (4) Sinuosity of closest segment of river. These attributes are then used to represent the grid points on the plots of shear strength parameter $\mathrm{Su}$ vs. the corresponding factors. 


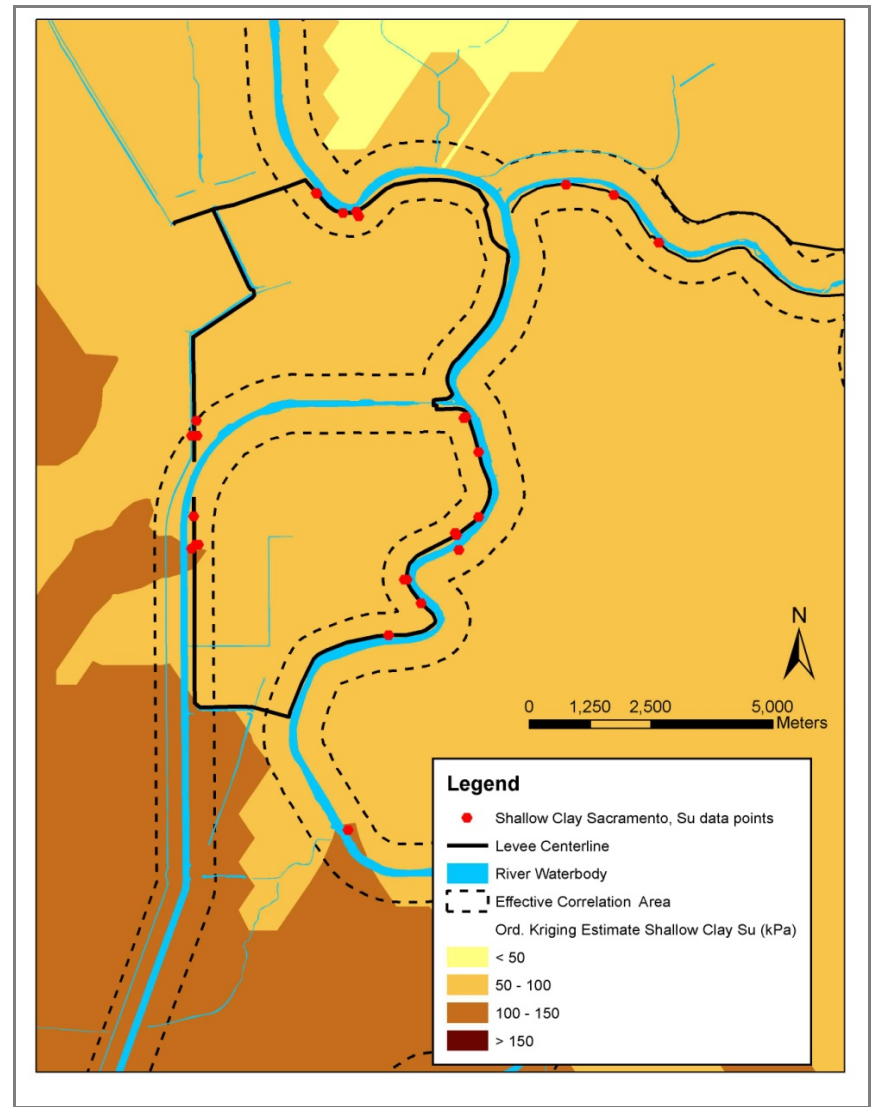

Figure 17. Sample output map of the ordinary kriging method applied for the $S_{u}$ values in shallow clay layer of Sacramento

Curve fits established between the soil strength parameters and the regional factors serve as a check to the ordinary kriging estimation method. Any grid location that exhibits values falling away from these established regional factor trends, will have its Su-kriging-estimate value revised in order to fall within an acceptable confidence level, i.e. a defined number of standard deviations, from the value at the best fit curve. Standard error/deviation can be defined for any distribution with finite first two moments, but it is most common to assume that the underlying distribution is normal. Once updates are made to all values that need adjustment, the kriging estimation map is recalculated, taking into account those updated values at the relevant grid point locations. The revised kriged map at the end of the modeling process is itself a continuous spatial distribution of the soil parameter estimates, and as such the value of the adjusted estimated parameter is read from any location within the effective correlation area on the map.

\section{Conclusions}

As a result of analyzing geotechnical investigation data in the area of study, the concept of "Effective Correlation Distance" between the soil parameters and regional factors is introduced. This is a physical representation of the distance beyond which no trend/correlation was observed or deemed physically significant. For clay parameters this distance came out to be $600 \mathrm{~m}$ from either side of the river centerline. For sand parameters the distance was $450 \mathrm{~m}$. Possible explanation of why sand distance is less than clay distance may be in the fact that sands settle closer to the levee in times of overtopping flooding due to larger heavier particle size as compared to silts and clays. Note that in Sacramento, the average river width is $150 \mathrm{~m}$, and levees are typically around $100 \mathrm{~m}$ from the river centerline (i.e. on average 25 meters from river edge). Thus, for example, the limit of this effective correlation distance for clays is still $500 \mathrm{~m}$ away from the levees, which can be approximated as free-field conditions.

Another concept established is the "Sinuosity Index Segmentation Level". This is a reflection of the river meander length period. Based on the available data, the ideal segmentation level was found to be close to 10 times the river channel width. Values imply that the Feather River $(1,000 \mathrm{~m}$ segmentation) has a shorter meander length than the Sacramento River $(1,750 \mathrm{~m}$ segmentation), i.e. the Feather River meanders in shorter meander 
wave lengths than the Sacramento River.

The main finding of the soil variability model is the establishment of a number of correlations between soil strength parameters (Friction Angle, $\phi$, for Sands, and Shear Strength, Su, for Clays) and a number of regional characteristics (underlying geology type, distance to river, and sinuosity of river). The correlations were studied for naturally occurring Clay and Sand typical foundation layers, located at both shallow and deep levels, in both regions of Sacramento and Feather Rivers.

The major findings from the development of the soil parameters estimation model, based on the above mentioned established correlations, are:

- Clay in both shallow and deep layers, and in both areas of study (Sacramento and Feather River), showed increasing trend of Su with increasing distance from river (Figure 14). Su values also increased with depth, which may be attributed to consolidation of the deeper layers over time.

- As for relation of Su to the different geological formations in the two study areas (Figure 15), a general observation is that clay Su values in the areas of the Qa formation (defined as Alluvium - unweathered gravel, sand, \& silt) tend to have lower values than other areas. The fact that clay is not the main component in this formation might provide an explanation for the lower values of $\mathrm{Su}$ for any clay showing in these areas, as compared to other formations.

- For Su relation to Sinuosity Index (Figure 16) there is a large scatter, at lower sinuosity levels. The higher number of data points at this low sinuosity level is due to the smaller number of river segments that are highly sinuous. An important observation across all areas of study, and at all depths of layers, is that Su tends to decrease with increasing sinuosity of the closest river segment. However, more data points are needed to develop more robust correlations between SI and shear strength or soil type. Furthermore, due to the specific case study area that was used, the limited data used was primarily available for SI values close to 1 (i.e. straight river sections).

- Sand layers in both shallow and deep, as well as in both areas of study, show an increase of friction angle, $\phi$, with increasing distance from river until a distance of $200 \mathrm{~m}$ from the river. Sands near the river are more likely to be "younger" deposits which would explain the relatively lower friction angles. The trend does not seam to be present beyond that distance, it should be noted however that there were much fewer data points available at long distances from the river.

- No clear conclusion could be drawn from the plot of friction angle, $\phi$, with respect to different geological formations in the two study areas. It is possible however to draw a relation between $\phi$ and individual geological formation (i.e. typical value and distribution of $\phi$ within each geological formation).

- For friction angle, $\phi$, relation to Sinuosity Index there is no global effect observed. $\phi$ values in Sacramento area decrease with increased Sinuosity levels, while in Feather River, there is no clear trend. Furthermore, the small number of data points at high sinuosity levels does not allow for further statistical analysis.

Global observations that apply across the larger area of study included the increasing trend of shear strength, Su, with increasing distance from the river, and decreasing trend of $\mathrm{Su}$ with increasing river Sinuosity Index levels. Only local trends were observed in the relation of friction angle, $\phi$, with Sinuosity Index, as well as in the relation of Su and $\phi$ with geological formations. This study also presents a framework that can be used for future studies in the development of spatial correlations of soil properties.

\section{Acknowledgements}

The authors would like to thank Matt Hartigan, undergraduate student at the University of Michigan, who helped with the processing of some of the shear strength data as part of the Undergraduate Research Opportunities Program (UROP) at the University of Michigan. The authors also wish to acknowledge Prof. Grengs from the School of Natural Resources and the Environment at the University of Michigan for serving on Mustafa Saadi's $\mathrm{PhD}$ committee and providing valuable feedback on the present study with respect to the use of the GIS platform. Finally, the authors are grateful to the Rackham School of Graduate Studies for awarding Mustafa Saadi the Rackham Graduate Student Research Grant during his last year at the University of Michigan.

\section{References}

ASCE. (2009). Report Card for America's Infrastructure. Retrieved May 6, 2009, from http://www.infrastructurereportcard.org/

ASCE. (2010). So You Live Behind a Levee? In American Society of Civil Engineers (Ed.). 
ASTM. (2011). ASTM Standard D2487-11 "Standard Practice for Classification of Soils for Engineering Purposes (Unified Soil Classification System)". ASTM International, West Conshohocken, PA, 2003, www.astm.org.

Athanasopoulos-Zekkos, A. M. (2008). Select Topics on the Static and Dynamic Response and Performance of Earthen Levees, Doctor of Philosophy. Berkeley, USA: Department of Civil and Environmental Engineering, University of California.

Athanasopoulos-Zekkos, A., \& Seed, R. B. (2013). Simplified Methodology for Consideration of 2D Dynamic Response of Levees in Liquefaction Triggering Evaluation. ASCE Journal of Geotechnical and Geoenvironmental Engineering (accepted for publication). http://dx.doi.org/10.1061/(ASCE)GT.1943-5606.0000913

Baecher, G. B., \& Christian, J. T. (2008). Spatial Variability and Geotechnical Engineering. In K. K. Phoon (Ed.), Reliability Based Design in Geotechnical Engineering: Computations and Applications. Taylor \& Francis.

Christian, J., \& Baecher, G. (2011). Unresolved Problems in Geotechnical Risk and Reliability. Proceedings of the ASCE GeoRisk2011: Geotechnical Risk Assessment and Management conference, Atlanta, GA (p. 3). ASCE.

Deretsky, Z. (National Science Foundation). (2010). Ten Ways a Levee Can Fail.

DRMS. (2006a). Delta Risk Management Strategy, Initial Technical Framework Paper: Levee Fragility.

DRMS. (2006b). Delta Risk Management Strategy, Initial Technical Framework Paper: Sacramento-San Joaquin Delta Risk Analysis (Approach and Basis of Analysis).

DWR. (2011). California Department of Water Resources. Retrieved September 5, 2011, from http://www.water.ca.gov/

FEMA. (2008). FEMA-366: HAZUS-MH Estimated Annualized Earthquake Loss for the United States. Retrieved September 1, 2009, from http://www.fema.gov/library/viewRecord.do?id=3265

Fenton, G. A., \& Griffiths, D. V. (2008). Risk Assessment in Geotechnical Engineering.

Gordon, N. D., McMahon, T. A., Finlayson, B. L., Gippel, C. J., \& Nathan, R. J. (2004). Stream Hydrology (2nd ed.). John Wiley \& Sons, Ltd.

Hatanaka, M., \& Uchida, A. (1996). Empirical correlation between penetration resistance and internal friction angle of sandy soils. Soils and Foundations. Japanese Geotechnical Society, 36, 1-9.

Helley, E. J., \& Harwood, D. S. (1985). Geologic map of the Late Cenozoic deposits of the Sacramento Valley and Northern Sierran Foothills, California. U.S. Geological Survey, Miscellaneous Field Studies Map MF-1790.

Hess, J. R., Sills, G. L., Costa, R., \& Shewbridge, S. (2006). California's Levees at Risk. Geo-Strata 7.

Julien, P. (2002). River Mechanics. Cambridge University Press, Cambridge, UK. http://dx.doi.org/10.1017/CBO9781139164016

Kulhawy, F. H., \& Mayne, P. W. (1990). Manual on Estimating Soil Properties for Foundation Design. Electric Power Research Institute, Palo Alto, Calif., Report EL-6800.

Lacasse, S., \& Nadim, F. (1996). Uncertainties in characteristic soil properties, Uncertainty in the Geologic Environment, ASCE specialty conference.

Lee, I. K., White, W., \& Ingles, O. G. (1983). Geotechnical Engineering.

Leopold, L. B., Wolman, M. G., \& Miller, J. P. (1964). Fluvial Processes in Geomorphology.

Lumb, P. (1966). The Variability of Natural Soils. Canadian Geotechnical Journal, 3, 74-97. http://dx.doi.org/10.1139/t66-009

Lumb, P. (1974). Application of statistics in soil mechanics. In I. K. Lee (Ed.), Soil Mechanics: New Horizons.

Lunne, T., Robertson, P. K., \& Powell, J. J. M. (1997). Cone penetration testing in geotechnical practice. Blackie Academic \& Professional.

Mount, J. F. (1995). California rivers and streams: the conflict between fluvial process and land use. Berkeley: University of California Press.

Mueller, J. E. (1968). An Introduction to the Hydraulic and Topographic Sinuosity Indexes 1. Annals of the 
Association of American Geographers, 58, 371-385. http://dx.doi.org/10.1111/j.1467-8306.1968.tb00650.x

Olsen, R. S., \& Mitchell, J. K. (1995). CPT Stress Normalization and Prediction of Soil Classification. Proceedings of the International Symposium on Cone Penetration Testing, CPT 95, Linkoping, Sweden.

Peck, R. B., Hanson, W. E., \& Thornburn, T. H. (1974). Foundation engineering. New York: Wiley.

Phoon, K. K., \& Kulhawy, F. H. (1996). On quantifying inherent soil variability, Uncertainty in the Geologic Environment, ASCE specialty conference.

RESIN. (2011). Resilient and Sustainable Infrastructure Networks project (RESIN) at the University of California, Berkeley. Retrieved November 11, 2011, from http://ccrm.berkeley.edu/resin/index.shtml

Robertson, P. K., \& Campanella, R. G. (1983). Interpretation of cone penetration tests. Part I: Sand. Canadian Geotechnical Journal, 20, 718-733. http://dx.doi.org/10.1139/t83-078

Schmertmann, J. H. (1975). Measurement of in-situ shear strength Proceedings. ASCE Specialty Conference on In Situ Measurement of Soil Properties, 2, 57-138.

Thorne, C. R., Hey, R. D., \& Newson, M. D. (1997). Applied Fluvial Geomorphology for River Engineering and Management. John Wiley \& Sons, Ltd.

URS. (2008). Technical Memorandum - Levee Seismic Vulnerability Assessment Methodology. In Urban Levee Geotechnical Evaluations Program (Ed.).

URS. (2010). Geotechnical Investigation data for West Sacramento, American River, Marysville, Sutter, and RD784. Received August 30, 2010. Personal Communication with Mr. Richard Millet, Vice President, Program Manager DWR Geo-Levee, URS Corporation.

USACE. (1987). Levee Investigation, Reclamation District's 537 and 900 and Maintenance Areas 4 and 9, Sacramento River, Sacramento Bypass and Yolo Bypass, Yolo and Sacramento Counties, California. Department of the Army, Office of the Chief of Engineers, U.S. Army Corps of Engineers.

USACE. (2013). Guidelines for the Seismic Evaluation of Levees, ETL 1110-2-580, Department of the Army, Washington, DC (in editing).

USGS. (2008). United States National Seismic Hazard Maps. Retrieved Multiple dates, 2010, from http://earthquake.usgs.gov/hazards/products/conterminous/2008/

USGS. (2010). National Map Viewer. Retrieved Multiple dates, 2010, from http://viewer.nationalmap.gov/viewer/

USGS. (2011). National Water Information System: Web Interface. Retrieved March 30, 2011, from http://nwis.waterdata.usgs.gov/nwis

\section{Copyrights}

Copyright for this article is retained by the author(s), with first publication rights granted to the journal.

This is an open-access article distributed under the terms and conditions of the Creative Commons Attribution license (http://creativecommons.org/licenses/by/3.0/). 